\title{
Biosemiotics and Applied Evolutionary Epistemology: A Comparison
}

\author{
Marta Facoetti and Nathalie Gontier
}

\begin{abstract}
Both biosemiotics and evolutionary epistemology are concerned with how knowledge evolves. (Applied) Evolutionary Epistemology thereby focuses on identifying the units, levels, and mechanisms or processes that underlie the evolutionary development of knowing and knowledge, while biosemiotics places emphasis on the study of how signs underlie the development of meaning. We compare the two schools of thought and analyze how in delineating their research program, biosemiotics runs into several problems that are overcome by evolutionary epistemologists. For one, by emphasizing signs, biosemiotics needs to delineate a semiotic threshold, which is a problem not encountered by evolutionary epistemologists. Instead, the latter recognizes that all organisms are knowers that evolve knowledge, which they recognize to extend toward phenomena produced by organisms such as behavior, cognition, language, culture, science, and technology. Secondly, biosemiotics attempts at continuing adaptationist notions on how organisms relate to their environment, while especially Applied Evolutionary Epistemology comes to redefine the nature of the organism-environment relationship in such a way that it recognizes the spatiotemporal boundedness of existence, which in turn makes adaptationist accounts obsolete.
\end{abstract}

Keywords Biosemiotics · Evolutionary epistemology · Applied evolutionary epistemology · Naturalized epistemology · Organism-environment relationship · Ontology-epistemology divide

\footnotetext{
M. Facoetti · N. Gontier $(\bowtie)$

Applied Evolutionary Epistemology Lab, Centro de Filosofia das Ciências, Departamento de História e Filosofia das Ciências, Faculdade de Ciências, Universidade de Lisboa, Lisboa,

Portugal

e-mail: nlgontier@fc.ul.pt
} 


\section{Introduction}

Evolutionary epistemology (EE) and biosemiotics are contemporary research fields similarly concerned with the evolutionary study of knowledge and knowing. In this chapter, we offer a comparative analysis of these schools of thought. We begin by briefly summarizing the basic tenets of EE (Sect. 2.1) and biosemiotics (Sect. 2.2), whereafter we highlight the contact points as well as the points of divergence that exist between these two schools (Sect. 3). We demonstrate that similarities are found in how both disciplines endorse evolutionary approaches to knowledge, but the two disciplines hold diverging views on how to understand evolutionary continuity in knowledge and semiosis (Sect. 3.1). Moreover, while both study knowledge from an evolutionary perspective beyond classic Neo-Darwinian theories of evolution, the disciplines emphasize different evolutionary mechanisms and processes (Sect. 3.2). Finally, we show that while both schools endorse constructivist and relativist approaches to knowledge (Sect. 4.1), especially Applied Evolutionary Epistemology (AEE) comes to redefine the organismal-environmental relationship in such a way that it overcomes problems of adaptation and semiotic threshold (Sect. 4.2).

\section{Two Naturalized Approaches to Knowing and Knowledge}

Both EE and biosemiotics share an interdisciplinary and evolutionary outlook on the study of knowledge. Biosemiotics thereby focusses on the semantics or meaningmaking aspects of knowledge, which is understood as sign evolution (Favareau 2007; Hoffmeyer and Emmeche 1991; Kull 2015; Sharov 2016). This tradition's intellectual roots reach back to pragmatism (James 1907; Peirce 1992, 1999) and semiotics (Eco 1984; Sebeok 1994; von Uexküll 1940), which are schools that developed in the philosophy of mind, language, and linguistics.

These just mentioned traditions also influence evolutionary Epistemology (EE) but EE is more an outgrowth of naturalized epistemology (Quine 1969; Popper 1972; Rorty 1980). EE developed further in association with the rise of ethology (Lorenz 1977) and comparative psychology (Campbell 1974a). Instead of focusing on the semantics of meaning-making, EE focuses on formally identifying the structure that grounds the evolution of epistemology, which is understood in terms of units, levels, mechanisms, or processes of knowledge evolution (Bradie 1986; Campbell 1974a; Hull 1988; Gontier 2006b, 2012; Plotkin 1994). This tradition associates more with the philosophy of biology, evolutionary biology, behavioral and cognitive sciences.

Both biosemiotics and EE have, throughout their intellectual development, also actively integrated important insights coming from cybernetics (Wiener 1948), information theory (Shannon 1948), general systems theory (von Bertalanffy 1968), and hierarchy theory (Pattee 1973; Salthe 1985; Simon 1962). In what follows, we offer introductory overviews of both disciplines. 


\subsection{Evolutionary Epistemology}

Evolutionary Epistemology (EE) is a research area of contemporary philosophy of science that studies the evolution of epistemology, i.e. the natural history of knowledge (Popper 1972), its evolutionary development or growth over time (Toulmin 1972; Hull 1988, Gontier 2006b).

Epistemology is understood as both the evolved act of knowing and as the outcome of knowing, which is knowledge that includes scientific theories but also behavior or cognition (Campbell 1974a; Hahlweg and Hooker 1989; Lorenz 1977; Munz 1993; Riedl 1984; Vollmer 1984, 1987; Wuketits 1992; 1998). In this regard, Bradie (1986) has distinguished EE into two research programs, EEM, that studies the Evolution of Epistemological Mechanisms responsible for knowing, and EET, that examines knowledge or the Evolution of Epistemological Theories.

The evolutionary study of knowing finds its intellectual roots in Naturalized Epistemology (Quine 1969) that understands knowing as a property of a cognitive organism (a knower) and, therefore, as something that can be studied from within the field of psychology. EE extends the latter's scope by recognizing that researching knowing is not merely a matter of psychological or cognitive research but also of evolutionary research. Not only humans or cognitive organisms, but all biological organisms are knowers that evolved knowledge. EE thus also includes studies of organisms such as bacteria or plants that do not have a brain but that nonetheless depict intelligible behavior. In this regard, EE also associates with the schools of ethology (Lorenz 1941; Tinbergen 1963) and comparative psychology (Campbell 1974a) that played crucial roles in "evolutionizing" the study of cognition and behavior, which are themes later also adopted by sociobiology and evolutionary psychology (reviewed in Gontier 2012).

For Evolutionary Epistemologists, knowledge is understood, on the one hand, to be embodied in evolved organisms and, on the other hand, to also extend biological organisms in phenomena preceded by them in time and phenomena produced by them throughout evolution (Bradie and Harms 2001; Campbell 1974a; Clark and Chalmers 1998; Facoetti 2020; Gontier 2006a; Hull 1988: Munz 1993; Plotkin 1994; Popper 1972; Toulmin 1972; Wuketits 1992, 2006). Examples of knowledge phenomena that precede life are molecular and biochemical processes that lie at the origin of life. Examples of extended knowledge are cognition, behavior, language, culture, science, and technologies portrayed and produced by living beings. These phenomena are understood to evolve over time, just like biological organisms do, and to embody knowledge.

Both embodied and extended knowledge also give new meaning to the concept of theory and its relation to the world (the epistemology-ontology divide). In this aspect, evolutionary epistemology is dividable into different schools of thought (Table 1).

Traditional EE (Popper 1963, 1972; Munz 1993) argues that knowing organisms provide unfalsified theories of an external world (Kant's Welt an sich or world-as-itis-in-itself). Non-Adaptationist EE (Wuketits 2006; Diettrich 2006; Riegler 2006) 
Table 1 Differences between traditional, non-adaptationist, and applied EE

\begin{tabular}{l|l|l|l}
\hline $\begin{array}{l}\text { Aspect of } \\
\text { difference }\end{array}$ & $\begin{array}{l}\text { Traditional } \\
\text { EE }\end{array}$ & Non-adaptationist EE & Applied EE \\
\hline $\begin{array}{l}\text { Evolutionary } \\
\text { framework }\end{array}$ & $\begin{array}{l}\text { Strict- } \\
\text { Neodarwinian }\end{array}$ & $\begin{array}{l}\text { Systems theory } \\
\text { (Eco-Evo-Devo) }\end{array}$ & Pluralistic \\
\hline $\begin{array}{l}\text { Explanation } \\
\text { Evolutionary } \\
\text { hierarchy }\end{array}$ & Reductionist & Holistic & Integrative \\
\hline Causation & Upward & Up- and downward & $\begin{array}{l}\text { Units, levels, mechanisms- } \\
\text { focused }\end{array}$ \\
\hline $\begin{array}{l}\text { Organism-envi- } \\
\text { ronment } \\
\text { relationship }\end{array}$ & $\begin{array}{l}\text { Dualistic, } \\
\text { adaptationist }\end{array}$ & $\begin{array}{l}\text { Dialectic, } \\
\text { non-adaptationist }\end{array}$ & $\begin{array}{l}\text { Cognitive, ecological, and socio- } \\
\text { cultural constructivism of } \\
\text { bio-realities }\end{array}$ \\
\hline Worldview & $\begin{array}{l}\text { Hypothetical } \\
\text { realism }\end{array}$ & $\begin{array}{l}\text { Coherence theory and } \\
\text { cognitive } \\
\text { constructivism }\end{array}$ & $\begin{array}{l}\text { Spatiotemporally-bounded } \\
\text { realism }\end{array}$ \\
\hline
\end{tabular}

instead claims that organismal theories are cognitive constructs coherent and functional for the organism, but we cannot know how it relates to an outer world-in-itself or whether the organism is adapted to it. Applied EE understands organisms and their extensions to continually alter and construct bio-realities, making the notion of a world-in-itself invalid. We briefly discuss the different schools.

\subsubsection{Traditional EE}

Original research within EE (e.g., Lorenz 1941, 1977; Popper 1963) operated within strict Neo-Darwinian evolutionary schools of thought that we criticize today for overemphasizing gene-reductionism and adaptationism and for endorsing dualistic views on how organisms relate to the environment.

Following Neo-Darwinian schools of thought, early supporters of EE assumed that organismal behavior was genetically determined and that, unable to change their genetic makeup, organisms passively undergo selection from an active environment. The environment was assumed to weed out maladaptive organisms, so only adaptive organisms survive. The organismal-environmental relationship was thereby explained in dualistic terms: organisms and the environment were considered distinct and homogeneous entities that interact only through natural selection (reviewed in Gontier 2006b).

Such an evolutionary view enabled early evolutionary epistemologists to endorse hypothetical realism, whereby, biology-wise, organisms were understood as adapted to their environment, and, epistemology-wise, their evolved knowledge on the environment was assumed to somehow corroborate to it (Popper 1963). 


\subsubsection{Non-Adaptationist EE}

Gene-reductionist and adaptationist perspectives became heavily criticized in biology. By building upon the works of Jakob von Uexküll $(1921,1928)$ as well as early developmental systems theory (Gould 1977; Maturana and Varela 1980) and ecology (Gould and Lewontin 1979), scholars reinstated an organismal-focused biology. This introduced a more dialectic understanding of how organisms interact with the environment. And it became recognized that organisms can construct ecological niches that are functional for the organism but these niches are not necessarily adapted to the outer world.

The systems-theoretical and constructivist approaches to evolution, in turn, inspired a new wave of evolutionary epistemologists who came to reject hypothetical realist accounts and to endorse instead non-adaptationist perspectives on knowledge (Diettrich 1998, 2001, 2004, 2006; Hahlweg and Hooker, 1989; Riegler 2001, 2006; Wuketits 1992, 2006; reviewed in Facoetti 2020, in press). For them, organismal knowledge, in so far as it is the outcome of evolution, is also constrained by its evolving cognitive apparatus and how it processes data from an outer and internal environment, what Lewontin (1983) called the "internalization of selection". That means that how organisms develop knowledge is determined by their biological makeup, and any act of cognition is, therefore, also an act of construction.

By integrating views from ecology, developmental biology, and systems theory, non-adaptationist EE has helped enlarge the scope of the Modern Synthesis toward what we now know as Eco-Evo-Devo (Ecological and Evolutionary Developmental theory). On their account, reductionism and adaptationism have to be replaced with more holistic explanations that allow for both up- and downward causation in development (Campbell 1974b) and a more dialectic perspective on the organismenvironmental relationship (Wuketits 1989, 17).

Contrary to adaptationist accounts, niche construction, be it ecological or cognitive, demonstrates a system's ability to self-maintain and self-organize (Maturana and Varela 1980) sometimes despite inhospitable environments (Lewontin 1983, 2000; Gontier 2018). The recognition that organisms construct ecological (Lewontin 1982, 1983), cultural (Odling-Smee et al. 1996), and cognitive ${ }^{1}$ (Magnani 2017) niches has made non-adaptationist evolutionary epistemologists assume that organisms preside over the construction of an experiential world. This world is not perforce connected with an outer reality (e.g., the Constructivist EE defended by Diettrich (2006) and the radical constructivism of Riegler (2006)). Instead, at an epistemological level, cognitive or behavioral traits need only be functionally or internally coherent (Wuketits 2006).

Nonetheless, non-adaptationist EE-ers continue to assume that there is a world-initself, and they are therefore faced with the question of how the constructed niches relate to such an "outer" world, ontologically speaking.

\footnotetext{
${ }^{1}$ Note that the concept cognitive niche is also used by Tooby and DeVore (1987) in an adaptationist context.
} 


\subsubsection{Applied EE}

More recently, Gontier (2018) has demonstrated that non-adaptationist approaches to $\mathrm{EE}$ are right in rejecting hypothetical realism and in recognizing the importance of ecological, cognitive, and sociocultural niche construction in knowledge formation instead. However, they are flawed in understanding constructed niches as distinct from a world as it is in itself. Like Kant, they thereby remain conflicted on how and if the noumenal world (ontology) relates to the phenomenal world (epistemology).

Such perspectives continue to separate organisms from environments, and biotic niches from an abiotic world, thereby assuming that the latter somehow forms a more stable and even essential ontological entity, void of or unaffected by the evolving and living world. Such a view falls short of recognizing the temporal and evolutionary aspects of the world. Instead, on Gontier's account, accepting evolution means that there no longer exists a world-in-itself. Rather, organisms constantly recycle existing matter into a living and ever-changing world. In such a world, epistemology defines ontology.

Epistemology refers to evolved knowledge that comes in the form of organisms and what extends them, and this defines ontology as a living and spatiotemporally changing earth. That means that earth is not a single stable entity but a result of constructed environments or biorealities. According to Gontier $(2018,30)$ :

The living earth evolves in congruence with these expanding (generating and/or speciating) and contracting (degenerating and perishing) bio-realities that are dependent upon organismal and species survival, reproduction and extinction as well as the ecological materializations they bring forth in time and space (or spacetime). Epistemology, understood not as theories but as the evolution of embodied knowledge in organisms and their extended niches that underlie bio-reality formation, therefore equals ontology, the currently living world. (Gontier 2018, 30)

The goal of AEE (Gontier 2017, 7-15) therefore is to investigate how different, species-specific bio-realities evolve and underlie the current living and evolving earth by adopting a pluralistic stance on units (parts) and levels (wholes) that together make up complex hierarchies (bio-realities) that underlie the ontological layeredness and variety of the evolving world.

Gontier characterizes this approach as "Applied Evolutionary Epistemology" (AEE) because it thinks through the consequences of non-adaptationist EE, and it applies EE not only to living organisms but to all aspects of the living earth.

\subsection{Biosemiotics}

Biosemiotics, as the name suggests, combines semiotics (a field in linguistics and philosophy that studies semiosis or sign processes) with biology (the study of living beings) (cf. Favareau 2007, 33; Brier 2006, 13) to study how biological organisms develop meaning through signs. 
Table 2 Semiosis

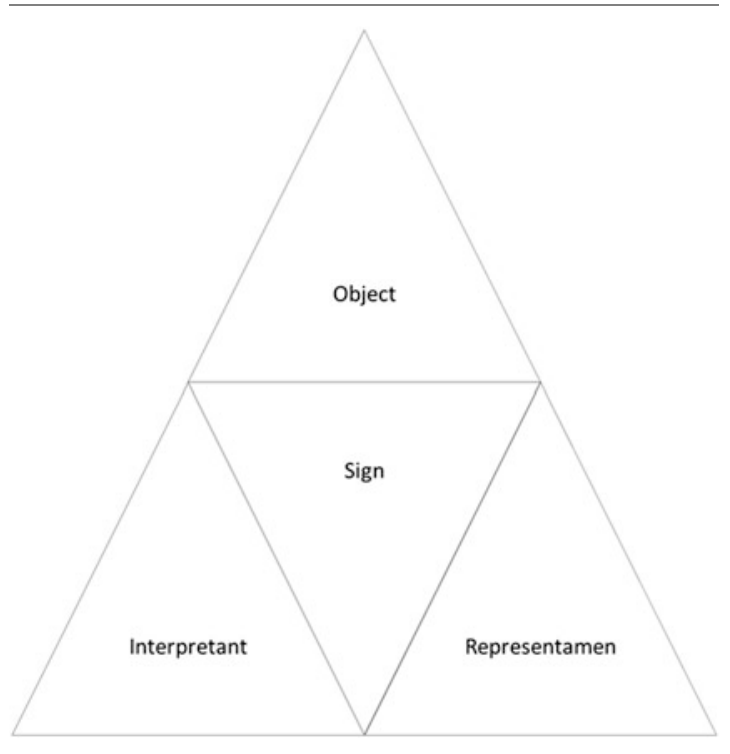

More specifically, biosemiotics can be defined as the "study of semiosis in living nature" and "biology as a sign system study" (Hoffmeyer \& Kull 2011; Kalevi 1998; Kull 2009a, b; Kull et al. 2011b, 15).

The goal of biosemiotics is to develop "a scientific understanding of how the subjective experience of organisms - as enabled differently by each species' particular biological constitution-comes to play a genuinely causal role in the ongoing co-organization of nature" (Favareau 2007, 33). Within such a perspective, semiosis underlies communication, and knowing is understood as a communicative and meaning-making process between organisms and the world. For Kull $(2014,48)$, for example, "knowing is possible only due to semiosis, through semiosis," and just like EE, biosemiotics can therefore be defined as the study of knowledge and knowing in all living systems (Brier 2006, 1), but knowing and knowledge are understood exclusively through the study of signs.

The semiotic part of "biosemiotics" goes back to a particular branch of semiotics introduced by Charles S. Peirce in the late nineteenth century. Peircean semiotics (Table 2) rests upon a triadic notion of the sign, which is understood as a relation between a representamen, an object, and an interpretant (Peirce 1931-1935). It furthermore adheres to a threefold classification of the sign relation between object and representamen, which can take on the form of icons, indexes, and symbols. Biosemioticians draw upon such classification in various ways, by relating different kinds of signs to different modes of semiosis in a variety of organisms (cf. Sharov and Vehkavaara 2015; Kull 2009c, 2018). 
The biological part of "biosemiotics" developed along the same lines EE and general evolutionary theory developed, from adaptationist-focused Neo-Darwinian schools of animal behavior and cognition to more extended views thereof. In addition, biosemiotics integrates the pre-constructivist view of Jakob von Uexküll (1921, 1928, 1937), which pivots on the Umwelt concept, the idea that the "perceptual world" ("all that a subject perceives") and the "effector world" ("all that he does") "together form a closed unit, the Umwelt" (von Uexküll 1934, 320). In this view, an Umwelt is "the set of features of the environment as distinguished by the organism, or the self-centered world that relates an organism with everything else" (Kull et al. 2011a, 38). Stated still differently, the Umwelt is the "species-specific model" of the world "incorporate[d]" by an organism (Sebeok 1996, 102; quoted by Kull et al. 2011a, 70).

With the Umwelt concept, von Uexküll put forward "a theory of meaning which considered animals as interpreters of their environment" (Sharov, n.d.) and signs as adaptations (Sharov 1999). Such a view is a form of pre-constructivism because it understands meaning as a form of "co-organization" (Favareau 2007, 33) between organism and environment. The concept also directly inspired Lewontin (1982), who introduced the niche construction perspective.

Gensini (2002, 123-127), for example, reports that semioticians agree that human semiosis has continuity with other species, firstly, by sharing the capacity for Umwelt formation and, secondly, because every living being is, like humans, capable of applying the "criterium of pertinence." This criterium refers to the capacity of distinguishing what is life-supportable from what is not (Gensini 2002, 124; translation ours). Finally, semioticians agree that different species-specific perceptual apparatuses and their associated categorical systems determine different species-specific relationships to species-specific worlds (Gensini 2002, 124).

In this regard, current biosemioticians share with supporters of non-adaptationist and applied EE an adherence to anti-reductionist views on evolution, where notions such as "function," "information," or "signal" are irreducible to chemical compounds or genes (Kull et al. 2011c, 31, 2011, 7; Sharov 1999). Especially biosemioticians have thereby also actively tried to incorporate teleological and vitalist notions (e.g., entelechy or goal-directedness) in biology by understanding organisms as living systems with selves, i.e. as self-organizing autonomous agents whose activities are "goal-directed" and "sign-dependent" (Sharov 2018, 197) (cf. Kull et al. 2011c, 27-32).

Furthermore, as theories within biosemiotics have developed and attempted to synthesize and integrate new schools of thought, von Uexküll's environmental Umwelt concept has been taken as synonymous with Maturana's notion of $a$ cognitive domain or Hoffmeyer's semiotic niche concept (Brier 2015, 578) in attempts to bridge the gap between the kinds of organisms that exist and the kinds of environments they inhabit.

Beyond the Peircean and Constructive/Umwelt approaches to biosemiotics, a third group of biosemioticians have attempted to reduce biosemiotics to "code biology" (Barbieri 2014) by trying "to refashion the primary biosemiotic articulation 
from one of 'sign' to 'codes"'. ${ }^{2}$ The latter is comparable to the search for universal formulas and heuristics of natural selection in evolutionary epistemology, such as the "blind variation and selective retention" schemes introduced by Campbell (1974a), or the "generate-test-regenerate" scheme of Plotkin (reviewed in Gontier and Bradie 2017).

\section{Digging Deeper for Similarities and Divergences}

In this section, we dig deeper into the similarities and divergences between EEs and biosemiotics.

\section{1 (Dis)Continuities in Knowledge and Semiosis}

Traditional, non-adaptationist, and applied approaches to EE overcome traditional empiricist, rationalist, and naturalist perspectives on epistemology that understood knowledge as "human-bounded," "cognitive," and "language-like" (Gontier 2006b).

EE evolved by recognizing the presence of knowledge in other organisms, and knowledge is extended to both the abiotic world and phenomena that evolved with the rise of living beings, such as behavior, cognition, languages, cultures, and technocomplexes.

Like evolutionary epistemologists, biosemioticians accept the idea of a certain continuity between humans and the rest of the world, but they also continue to look for a semiotic threshold. However, this threshold has proven to be the Achilles heel of contemporary biosemiotics. It currently functions as a source of debate, critique,

\footnotetext{
${ }^{2}$ According to scholars of the International Society for Code Biology (http://www.codebiology.org/ ) (i.e., Barbieri together with Stefan Artmann, Joachim De Beule, Peter Dittrich, Almo Farina, Dennis Görlich, Hendrik Hofmeyr, Stefan Kühn, Chris Ottolenghi, Liz Swan, Morten Tønnessen, and Jan-Peter Wills), Peircean biosemiotics is incapable of providing "a scientific approach to the semiosis of Nature" (Barbieri 2014). Hence, by distancing themselves from Peircean biosemiotics and by working from within a new theoretical framework called "code biology," these scholars aspire to provide such "a scientific approach" through "a study of all codes of life with the standard methods of science" (Barbieri 2014). For a review of other critical perspectives on Peircean biosemiotics and biosemiotics in general, the reader may refer to (Favareau 2007), who points to the existence of both "informed" and "uninformed criticism" of such view. According to Favareau $(2007,45)$, whereas insiders of biosemiotics generally put forward the former (he cites Vehkavaara (2002, 2003) and Artmann (2005), among others), the latter is mainly proposed by "those critics from the outside" to whom he attributes a misunderstanding of the theory. As we will see, the Constructive approach to biosemiotics discussed in this paper (and of which Vehkavaara is one of the leading advocates) is critical of Peircean biosemiotics and, more specifically, of its understanding of the "sign" notion.
} 
and diversion into different schools because scholars disagree amongst themselves where that threshold can be found and what the minimum semiotic entity is.

The term "biosemiotics" was coined by Rothschild (1962) and initially focused on studying human knowledge. On noticing that the processes that underlie sign elaboration in animals were not different from those characterizing human semiosis, in the 1970s, Sebeok extended semiotic notions to other animals, in the field he called "zoosemiotics" (Sharov n.d.; cf. Kull et al. 2011c, 25). Further studies in the 1980s showed that semiosis is not limited to organisms with a nervous system (Sharov n.d., cf. Brier 2006, 16-17). Sebeok eventually argued that the semiotic threshold is "co-extensive with [the] life/non-life distinction" (Kull et al. 2011c, 27).

For Sebeok (1994, 3), semiosis is understood as "the instinctive capacity [or "biological capacity" (p. 8)] of all living organisms to produce and understand signs." Organisms differ in how "[e]ach species produces and understands certain kinds of specific signs for which it has been programmed by its biology" (Sebeok 1994, 3; italics ours). In this regard, Sebeok also distinguished between endosemiosis or semiosis that occurs inside organisms (the processes that underlie sign production) and exosemiosis or semiosis that occurs between organisms (e.g., communication) (Brier 2006).

Brier (2006, 16-17) distinguishes semiosis in humans (anthroposemiosis), animals (zoosemiosis), plants (phytosemiosis), fungi (mycosemiosis), protists (protistosemiosis), and bacteria (bacteriosemiosis). Kull (2009c, 2018) instead distinguishes between "vegetative semiosis, which is based on iconic signs, animal semiosis, which is based on indices, and cultural semiosis that is ... based on symbols" (reviewed in Sharov and Vehkavaara 2015). These different kinds of semiosis associate, respectively, with a vegetative, animal, and cultural Umwelt (Kull 2009c, 2018). Kull (2018) speaks of a fourth kind of semiosis, namely "social semiosis," and a related fourth kind of Umwelt (social and emotional Umwelt), which is based on "emons." Other scholars have introduced the notion of ecosemiotics (Nöth 1998).

These distinctions bring to light the division that exists between organismfocused and Umwelt-focused approaches to biosemiotics. Divisions between plants, animals, protists, etc., recall the old 5-kingdom classification of life (Whittaker and Margulis 1978), but this distinction is now being replaced by a 3-domain classification of life (Woese et al. 1990). These distinctions are also problematic because they, by and large, remain organism-centered. As many biosemioticians insist on semiosis requiring agency and selves, they fail to recognize complex biochemical processes, on the one hand, and sociocultural, linguistic, or technological innovations on the other as knowledge or signs. Those that do are more inspired by the Umwelt or niche construction notions associated with culture and ecology, but in doing so, these distinctions attempt at bringing in non-living entities into the semiosphere.

While Sebeok took living beings as the only entities capable of semiosis, biosemioticians today find no unanimity in defining life and defining the minimal semiotic entity. On the one hand, as Sharov $(2018,202)$ explains, biosemioticians such as Bruni (2008), Hoffmeyer and Emmeche (1991) maintain that cells are the minimal living systems capable of semiosis because they "have enough complexity 
to interpret signs in a Peircean way." ${ }^{3}$ As Sharov $(2018,202)$ reports, these scholars maintain that it is impossible to "apply the notion of signification to molecular processes such as DNA replication, transcription, and translation on the grounds that these processes are mechanistic, and therefore, not semiotic." Lacking selves, no subject does the interpreting or meaning-making.

On the other hand, and in dissent with this Peircean view of semiosis, scholars such as Sharov and Vehakavaara (cf. Sharov and Vehkavaara 2015) believe that " $[\mathrm{t}]$ he denial of signification at the level of functional molecular complexes and organelles is a regrettable mistake." They also think that "[t]he origin of signs and meanings should be moved back in time to the origin of life in the form of simple functional and heritable molecular networks" (Sharov 2018, 202). Moreover, and arguing from within a position they characterize as Constructive biosemiotics, these scholars maintain that Peirce's notion of the sign cannot indiscriminately be applied to all levels of semiosis (vegetative, animal, and cultural [cf. sect. 2.2.]) (Sharov 2018). In fact, they maintain that whereas Peirce's notion of sign does always imply the act of representing an object (Sharov and Vehkavaara 2015; cf. sect. 2.2.), "[t]he capacity to perceive and classify objects (...) is limited in primitive organisms" and "most simple organisms, such as bacteria, entirely lack this capacity and associate signs directly with actions rather than with objects" (Sharov et al. 2015, 6). Constructive biosemioticians, therefore, propose to distinguish between two kinds of semiosis: "protosemiosis" and "eusemiosis" (cf. Sharov and Vehkavaara 2015; Sharov 2015, 2018). Protosemiosis is taken to coincide with "the origin of life" (Sharov and Vehkavaara 2015) and identified with vegetative semiosis. Its basis is the notion of "proto-signs," which comes to replace Peirce's notion of icon (Sharov and Vehkavaara 2015). Eusemiosis is taken to start with "the origin of minimal mind" (Sharov and Vehkavaara 2015), that for these scholars coincides with the origin of animal and cultural semiosis. It is based upon the Peircean notions of sign (icon, index, symbol), whereby "agents associate signs with objects and only then possibly with actions" (Sharov et al. 2015, 6).

In sum, contemporary biosemiotics brings forth a more hierarchical and temporal view of the environment that becomes divided into several realms in congruence with the historical evolution of life on earth and how it evolved meaning-making. However, such a view continues to distinguish organisms from environments and may form a source of conflict when we consider it systematically. The emphasis placed on organisms as selves capable of meaning-making or interpretants of signs has resulted in biosemioticians running into conceptual problems when attempting to consider ecological and cultural processes, on the one hand, and biochemical processes, on the other.

On the other hand, AEE does not take life or living organisms as the boundary of knowledge, and this enables AEE to move about freely in identifying abiotic and

\footnotetext{
${ }^{3}$ According to Peirce's theory of signs, "semantic links between representamen and their interpretants are based on the association with objects; and thus, appear grounded in the real world" (Sharov 2018, 202).
} 
non-biotic or from-life-evolved phenomena such as technocomplexes as knowledge and information.

\subsection{The Scope of Evolution and the Importance of the Organism}

Both EE and biosemiotics understand knowledge/semiosis as an evolved phenomenon. Both agree that the knowledge that organisms gain or produce is fundamentally constrained by evolution (Gontier 2018, 541), and it bears with itself the marks of its evolutionary history (cf. Wheeler in Favareau et al. 2017, 10). While both adhered initially to adaptationist views, today, both fields expand narrow Neo-Darwinian theories of evolution and integrate ideas associated with extensions of the Modern Synthesis and non-Darwinian evolutionary theories.

Neo-Darwinism is a school of thought that understands natural selection as a two-way process. Genes underlie the formation of anatomical, functional, and behavioral traits, and these enable organisms to establish a perfect fit with their environment (Dawkins 1983). In such a view, organisms and environment interact only through the process of natural selection and ontogeny, the development of an organism from conception until death, becomes separated from phylogeny, the evolution of species. Such a view is dualistic because organisms are understood as passive entities that become selected only when adapted and discarded when not by an active environment (reviewed in Gontier 2006b).

Today, evolutionary epistemologists and biosemioticians distance themselves from such a Neo-Darwinian understanding of evolution. As a forerunner of evo-devo, von Baer's evolutionary developmental theory already inspired Jacob von Uexküll at the beginning of the twentieth century to understand organisms as active agents interacting with their environment rather than being passively selected by it (Kull 1999, 391). In turn, inspired by von Uexküll, today, evo-devo has also expanded toward ecological theory into the new field of eco-evo-devo where biosemioticians such as Sharov et al. (2016) and Kull et al. (2011c) find inspiration (cf. Kull 1999, 407). In such theories, these biosemioticians find "the agential properties of life and emphasiz[e] the autonomy and goal-directedness in the activity and communication of organisms" (Sharov 2018, 199). Because ultimately, biosemioticians aim to integrate evolutionary theory with a "theory of reference and interpretation" in order to explain "the teleological nature of living systems" (Hoffmeyer 2010, 368), that is "in order to make explicit. . such unanalysed teleological concepts as function, adaptation, information, code, signal, cue, etc...," which for them do essentially characterize living processes (Hoffmeyer 2011, 64).

Like biosemioticians, evolutionary epistemologists have come to favor non-adaptationist theories of evolution over adaptationist or Neo-Darwinian ones. However, contrary to biosemioticians, most evolutionary epistemologists have refrained from incorporating teleology and purpose or natural finality into biology. 
Non-adaptationist evolutionary epistemologists have thereby been fighting at the front line to embrace the Modern Synthesis's extensions that build upon the achievements of eco-evo-devo theories that include recognizing phenotypic plasticity, niche construction, and a more significant role for drift theory. These theories recognize organisms as active entities that can condition their chances of survival. Also reinstating an organismal point of view rather than a gene or environmental point of view, along these lines, constructivist approaches have come to replace a dualistic perspective on the organism-environment relation with a dialectic one in which organisms preside over the construction of a species-specific experiential world which is not necessarily connected with an external reality (reviewed in Gontier 2018, Facoetti, in press).

AEE, in particular, has also thought through the consequences of reticulate and constructivist evolutionary theories for evolutionary epistemology. Within this perspective, the relationship between organisms and their environment is "exclusive because there is no outer abiotic earth anymore" (Gontier 2018, 545).

In this context, it is essential to emphasize that both biosemiotic and non-adaptationist evolutionary epistemological schools of thought have been deeply influenced by the 1960s-1980s research in systems theory (von Bertalanffy 1968) and (bio-)cybernetics (Maturana 1970; von Glasersfeld 1981, 1984). This new wave of theoretical biological studies had a substantial impact on research in evolutionary biology, which, as Kull $(1999,405)$ reports, in the last decades of the twentieth century started to put an unprecedented emphasis on the "form and activity of organism[s]." Such theories distinguished themselves by proposing a holistic view, an organism-centered perspective that highlights the autonomous nature of organisms. Based on these new perspectives, the study of organisms as wholes ceased to be reduced to the study of their physicochemical parts. Organisms came to be viewed in all their complexity, as "integrated wholes," that is, as "hierarchically organized, stratified, multi-levelled systems with dynamic interaction between all levels" (Löwenhard 1989, 90). Moreover, organisms came to be understood as autonomous systems capable of self-organizing and self-regulating (cf. Maturana and Varela's [1980] concept of autopoiesis), sometimes even despite the environment. As seen, whereas biosemioticians have come to emphasize the teleological character (i.e., the goal-directedness) of such self-organizing and self-regulating activities, non-adaptationist scholars and applied evolutionary epistemologists have mostly put the accent on the independent character of such activities from an outer world.

\section{Defining the Organism-Environment Relationship: Old and New Cosmologies}

Both EE and biosemiotics reject reductionism, the idea that higher biological phenomena can be reduced to underlying physicochemical processes (Brigandt and Love 2017). In line with this and influenced by Bertalanffy's system theory, 
both non-adaptationist and applied EE, and biosemiotics, in its Peircean and Constructive interpretations, do furthermore maintain that there is autonomy at the organismal level as organisms are autonomous (autocatalytic, autopoietic, i.e. selforganizing) systems which cannot be explained merely by their parts.

Within such perspectives, the denial of a reductionist stance goes hand in hand with the rejection of Cartesian dualism, i.e. the idea of there being a rigid division between mind and body and between organisms and the outer world.

In taking on a non-Darwinian perspective on evolution and a biological line of thinking informed by research in biocybernetics and systems theory, both EE and biosemiotics come to reject structural realism - the idea that there exists an independent outer world of which organisms can know its structures. They also reject the notion of truth as correspondence - the idea that organismal theories about the world can be true if they correspond to or accurately describe its structures (cf. Diettrich). Today, both Non-Adaptationist and Constructivist evolutionary epistemologists (Wuketits, Diettrich, Riegler) and biosemioticians (both Peircean and Constructive ones) suggest similar alternatives to the traditional interpretation of the organism-environment relationship. In so doing, they maintain a distinction between ontology and epistemology. Applied EE, on the other hand, goes beyond the traditional ontology/epistemology divide.

\subsection{Non-Adaptationist EE and Biosemiotics Offer Similar Epistemologies and Ontologies}

The epistemological and ontological accounts that non-adaptationist EE and biosemiotics put forward to explain the organism-environment relationship are similarly characterized by the appeal to constructivism, relativism, idealism, and functional realism.

Within non-adaptationist EE, dualistic pictures of the organism-environment relation are rejected through the appeal to functional realist accounts (Wuketits) or complete ${ }^{4}$ constructivist perspectives (Diettrich and Riegler). By embracing such positions, non-adaptationist evolutionary epistemologists maintain that organismal knowledge of the world is always relative to the organism's species-specific cognition and anatomy. Such knowledge, they hold, should not be evaluated on the grounds of its correspondence to the structures of an outer world, but in light of its coherence with the whole of an organism's experiences, whether it is lifesupportable and functional to the survival and fitness of organisms (Wuketits

\footnotetext{
${ }^{4}$ We use the term "complete" to refer to Diettrich's Constructivist EE (CEE) and Riegler's Radical Constructivism. Both authors resort to such an adjective (Diettrich 1998; Riegler 2001) to mark the distance between their positions and von Glasersfeld's Radical Constructivism. Contrary to the latter, Diettrich and Riegler endorse a kind of constructivism "on all levels" (Riegler 2001, 7) (reviewed in Facoetti 2017, 3).
} 
2006, 40), viable (Riegler 2001, 6), reproducible, and consistent (Diettrich 2001) (discussed in Facoetti 2020, in press).

On the one hand, Wuketits embraces relativism and moderate constructivism. For him, organisms and their environment are engaged in a mutual relationship, whereby the environment defines organisms' adaptation, and organisms define adaptability (i.e., by niche construction) (Wuketits 2006, 38) in light of their inner world or species-specific needs and experiences (Wuketits 2006, 43). In such a view, the organismal view of the world does not need to be in 1 to 1 correspondence with an outer world, but following the ideas of von Glasersfeld (1995), it needs to be functionally coherent for the organism, and it needs to enable survival in the environment. For Wuketits $(2006,44)$, according to a functional realist point of view that reality is what is functional to the survival of an organism, "there is no need for the belief in the unknowable - and thus no need to assume the existence of an unknowable world-in-itself." Wuketits $(2006,43)$ considers the notion of a world-initself "obsolete or at least redundant," as "what counts for any organism is that it copes with its own world properly." Nonetheless, "what an organism constructs must, one way or another, correspond to some aspects of reality" (Wuketits 1992, 158) because "any organism that would totally neglect the outer world and rely exclusively on its own constructions would not survive" (Wuketits 2006, 43).

On the other hand, relativism and complete constructivism characterize the views of Diettrich (1998, 2001, 2004, 2006) and Riegler (2001, 2006), both of whom distance themselves from von Glasersfeld's radical constructivism and hence from the idea that the experiential world that our mind "has priority in constructing (...) necessarily relate to an outer world" (Gontier 2018, 545). On von Glasersfeld's account, as framed by Diettrich $(2004,61)$, knowledge still has to meet external reality requirements, although "not necessarily by means of delineating environmental structures but rather functionally." Opposing this view, Diettrich and Riegler espouse an agnostic perspective, according to which we are neither in the condition of negating the existence of such reality nor claiming "its non-existence" (Riegler 2001, 3). By drawing upon Piaget (1970), Diettrich (1998) pictures the organismenvironmental relation in terms of a reconstruction-construction process, whereby the act of assimilation (construction) alternates that of accommodation (adaptation/ reconstruction) by giving rise to a continuous feedback circuit (reviewed in Facoetti 2020, in press). Along these lines, as Diettrich (2004, 61) reports, within such perspectives, knowledge is considered to be reliable if it "derive[s] from perceptions and their appropriate interpretation, but neither perceptions nor their (viable) interpretations need the evaluation by an external world." For his part, Riegler $(2006,51)$ proposes a radical "subject-centered" interpretation of the organism-environment relation according to which organisms actively construct species-specific experiential worlds which do not perforce relate to an external world.

Like new evolutionary epistemologists, biosemioticians reject dualistic views on the organism-environment relation by subscribing to a pragmatist/functionalist position (Sharov, Wheeler) or an idealistic approach to semiotics (Sebeok). In particular, Sharov $(2016,15)$ sees in constructivism "a valuable addition to biosemiotics because it emphasizes the activity of agents in self-construction, self- 
reproduction, and development of sign relations." Sharov $(2016,2018)$ draws upon Vygotsky's constructivist position ("historical-dialectical-monism" or "functional monism" [Liu and Matthews 2005, 397]) as well as on von Glasersfeld's radical constructivism (Sharov 2018, 203). Vygotsky's dialectical constructivist position allows Sharov "to go beyond the boundaries set by dualism, and to see how man and world, mind and reality can become the source of growth and change for each other" (Liu and Matthews 2005, 397; italics ours). Von Glasersfeld's radical constructivism, in turn, enables him to picture organisms as "self-constructed unities" whose "knowledge fits reality in the Darwinian sense [i.e. by adaptation], but does not necessarily include a representational relation to it" (Sharov 2018, 203).

Just as new evolutionary epistemologists, biosemioticians also embrace a relativist view, according to which knowledge is always relative to an organism's Umwelt and mediated by species-specific cognitive and perceptual faculties, apt to satisfy species-specific needs. Besides, similarly to new non-adaptationist scholars, biosemioticians replace structural realist perspectives on the knowledge-world relation with idealist or pragmatist/functionalist standpoints.

Sebeok (1994) espouses a semiotic idealist view that comes close to Riegler and Diettrich's stance. On Sebeok's account, the mind presides over the creation of a structured and meaningful world (Umwelt) "out of a vast and diverse crush of sense impressions” (Sebeok 1994, 37). To Sebeok (1994, 34):

Whether there is a reality behind signs-perhaps what Heraclitus called logos, the repeatable structure that secures for any object its ideal unity and stability (...) - -humanity can never be sure.

Within this perspective, as Deely $(2013,35-38)$ explains, the idea of an independent external world comes to be understood as "a species specifically human representation": "[w]e awaken not to a physical environment of pure ens reale but to an objective world which, like that of every animal, is a mixture of ens rationis and ens reale." The notion ens reale "is neither identical with 'the external world' nor the starting point as such of species-specifically human knowledge, but merely a recognizable dimension experienced within objectivity," our human-specific experiential world (Deely 2013, 38).

Sharov's Constructive biosemiotic view, on the other hand, comes close to that of Wuketits (1992, 2006), as he adopts a pragmatist or functionalist perspective which "does not view existence as objective (i.e., observer-independent) reality." According to Sharov (1999), "existence" should be "evaluated subjectively according to its expected effects on the existence of other things in the future": "food exists for an animal because it increases chances of [i.e. it is functional to] survival and reproduction (i.e., existence) of this animal." In Sharov's view, knowledge still has to fit (some parts of) reality-organisms must adapt to reality. Otherwise, they could not survive, although such knowledge does not need to represent reality accurately (Sharov 2018, 203).

Like Sharov, Wheeler (in Favareau et al. 2017, 10) espouses a functionalist point of view, according to which organisms construct a subjective world out of what is functional to their survival: 
The world of our senses does not reveal the whole world to us. Even at the level of simple objects, we sense only what we need to sense to get on with caring about being. This means that news of the world arrives in the form of signs that "stand in for" the world's inaccessible plenitude: signs that shine and compel us. (Wheeler in Favareau et al. 2017, 10)

Wheeler's view is part of the Peircean approach to biosemiotics, which traditionally maintains an outer world's existence, a purely physical and singular realm (Kull 2015, 523). According to Peircean biosemioticians (Kull, Pattee, Emmeche, Hoffmeyer), such an outer world is dominated by physical laws, which, by definition, are "universal," "singular," and "inexorable" (Pattee and Kull 2011, 220; Kull 2015, 522-523). Organisms appear to "locally escape the global behavior of physical laws, yet without ever disobeying them" (Pattee and Kull 2011, 222). In other words, organisms are "active systems of sign production, sign mediation and sign interpretation, that harness the physical laws in order to live and sometimes to make a more complex living" (Kull et al. 2011c, 1). The realm of living creatures, that is, the realm of semiosis, is dominated by semiotic rules or regularities (Pattee and Kull 2011; Kull 2018). The latter, in contrast to the universal and singular character of physical laws, are non-universal but "local" and "plural" (Pattee and Kull 2011; Kull 2015, 2018).

A supporter of the Peircean paradigm, Kull replaces the Cartesian division between mind and body and organism and the world with the distinction between "signness" and "non-signness" (cf. Kull 2015; Kull et al. 2011c; Pattee and Kull 2011; Kull 2018). For Kull (2018, 145), this division lies between the domain of "semiotic regularities" that can be learned and that of physical laws that are given. For Kull $(2018,142)$, the possibility of constructing (or representing) space, for example, is connected to the learning of particular signs relations. The construction of space is needed for "the modelling and construction of the Umwelt," and this process, in turn, depends upon learning sign-to-sign connections (Kull 2018, 142). The vegetative Umwelt is "an umwelt in which space cannot be constructed" as "there is no sign-to-sign connectedness due to the absence of associative learning" (Kull 2018, 142). However, in the animal Umwelt, "[t]he availability of indexes in addition to icons (as a result of associative learning) makes a huge difference in the representation of the world" as it becomes possible to construct space (Kull 2018, 143).

\subsection{Applied Evolutionary Epistemology (AEE) Beyond the Ontology/Epistemology Distinction}

As mentioned, new evolutionary epistemological and biosemiotic schools of thought rely on an old cosmology, which, as just seen, rereads the organism-environment relationship in light of the traditional ontology/epistemology distinction. Within such cosmological perspective, organisms either try to gain knowledge about an outer independent world ("the universe, earth, an abiotic environment, or a "more 
fundamental' physicalist level") or, at the opposite pole, they appear to construct a world of their own in their minds (Gontier 2018, 550). Such cosmology and the underlying ontology/epistemology distinction, as Gontier $(2018,539)$ notices, were developed before "the recognition that we live in an evolving world that forms part of an expanding universe and possibly a multiverse." Today, due to advances in physics, socio-anthropological sciences, and evolutionary epistemological schools of thought, this understanding of the organism-environment relations appears no longer tenable (Gontier 2018, 546).

The newly developing cosmology shows that, contrary to what functionalist/ dialectic/pragmatist approaches to EE (Wuketits) and biosemiotics (Sharov) maintain, "there is no single static cosmos 'out there' that organisms acquire knowledge on or adapt to" (Gontier 2018, 549). Such schools of thought draw upon current niche construction theories. These theories "understand organisms to primarily conform or adapt to a given and somewhat stable biological or socio-cultural environment which are the niches constructed and only in a later phase can individuals modify it" (Gontier 2018, 546). Gontier points out, however, that functionalist/ dialectic/pragmatist schools of thought underestimate "the creative power organisms have in continuously bringing forth new niches, new bionts, and new holobionts." According to Gontier (2018, 546-547):

\footnotetext{
Niche construction theory can fare much better by abandoning both its notions of adaptation and adaptability. These are non-evolutionary because they accept an outer, somewhat stable world. Adaptation or superorganic realms are concepts belonging to older cosmologies, they are not part of the new worldview that is developing. For the same reason, we shall also surpass Levin \& Lewontin's (1985) Hegelian and Marxist dialectic position.
}

For the same reason, new evolutionary epistemological and biosemiotic positions that draw upon functional, dialectic, and pragmatist ideas should be surpassed. Also, in opposition to complete constructivist (Diettrich and Riegler) and semiotic idealistic (Sebeok) perspectives, the new cosmology demonstrates that organisms' constructive activities are not confined to their minds: "organisms reconstruct the earth, not just in their minds, they embody that knowledge in their anatomy and cognition, and they extend it onto their progeny and into the niches they construct" (Gontier 2018, 545). Moreover, contrary to those biosemioticians (Kull, Emmeche, Hoffmeyer, Pattee) who support the idea of an outer physical world, the "newly evolving cosmology" shows that there is no longer room for the idea of an abiotic world (Gontier 2018, 551):

\footnotetext{
Ever since life evolved, life has rebuilt earth inside out, recycling existing matter, energy and space made in previous moments in time, into a living earth, up to the point that earth no longer exists as a purely physical "outside" entity. If that abiotic entity once existed, it now exists no more. Rather, it evolved into a living planet through the organisms that reconstruct it from its subatomic particles onward by reproducing and constructing new material life forms as well as extended and equally material niches. (Gontier 2018, 545)
}

In light of this, those evolutionary epistemological and biosemiotic standpoints that rely upon complete constructivist and semiotic idealist perspectives or that embrace the idea of an outer physical world should also be surpassed. Ultimately, the traditional epistemology/ontology should be abandoned: 
Organisms and the environments they build (epistemology understood as evolved knowledge) are what is real (ontologically), and the relation is exclusive because there is no outer abiotic earth anymore. Our living planet is not just hypothetically real, it is spatiotemporally real, or stated otherwise variant in time and space. (Gontier 2018, 545)

On the grounds of this new cosmology, Gontier's AEE proposes to go further than new EEs and biosemiotic schools of thought by framing the organism-environment relationship within an innovative, radical spatiotemporal realist perspective, in which constructivist and relativist notions come to acquire brand-new meanings. Within AEE, organisms are niches constructors that are also habitable zones of life for other organisms, engaged in the continual activity of creating new bio-realities and molding their extended niches (Gontier 2018, 550).

Within this view, the construction of niches no longer implies the notions of adaptation and adaptability, as the idea of an outer world comes to be supplanted by that of multiple evolving bio-realities which modify, recycle, and ultimately replace physical earth (Gontier 2018, 550). The latter, once "a purely physical or physicochemical object," no longer exists as it has left the place to "expanding and contracting biologically-informed realities or bio-realities" (Gontier 2018, 551). On the other hand, since knowledge is identified with "an evolving phenomenon that materializes into organisms and the overlapping biological realities they construe" (Gontier 2018, 550), within AEE, knowledge comes to equal reality, or, in other words, epistemology comes to equal ontology, understood as "the current living world" (Gontier 2018, 545). In light of this, within AEE, the evaluation of knowledge does not longer imply a comparison with an outer physical world. Along these lines, AEE comes to subscribe to a relativistic or pluralistic account, according to which truth evolves over time and space and varies from organism to organism, from niche to niche (Gontier 2018, 554-557). Eventually, within AEE:

The question is not who is right or wrong, but how distinct insights from different human cosmologies and other organisms together provide a deeper understanding of the complex and multiple realities that life has evolved up until today, and how we can move forward from there. (Gontier 2018, 557)

\section{Conclusion}

The comparison of EE and biosemiotics has provided a viewpoint to appreciate the respective extensions of these two disciplines, observe their specific conformation, and locate the points of mutual intersection and sharp separation.

Although EE and biosemiotics aim at different targets, in Sect. 3, we have demonstrated that it is possible to draw some parallels between these schools of thought, especially when considering Non-Adaptationist and Applied versions of EE in comparison with the Peircean and Constructive interpretations approaches to biosemiotics. A systematic analysis has furthermore revealed differences in how the disciplines understand and make use of the same ideas.

For one, both EE and biosemiotics recognize evolutionary continuity between humans and other beings. However, whereas biosemioticians preserve knowledge 
for inhabitants of the living realm, where it becomes identified with the domain of semiosis, Adaptationist, Non-Adaptationist, and Applied EE extend knowledge to phenomena produced by living organisms (behavior, cognition, languages, cultures, science, and technocomplexes), and especially with AEE, such a continuum is even further extended toward the non-living world. As such, all EEs avoid running into the conceptual problem faced by biosemioticians in having to demarcate a biosemiotic threshold in order to define the minimal semiotic entity. Biosemioticians' continued emphasis on semiosis or interpretation and meaningmaking by individual agents of the world explains their lack of references toward technological, sociocultural, and linguistic phenomena, as well as to abiotic phenomena that lack selves. Evolutionary epistemologists, however, do not require the identification of agency or a semiotic threshold to identify information and knowledge. They can instead move about freely in identifying biotic and from-life-evolved phenomena as well as abiotic and non-biotic phenomena as embodying information and knowledge.

Secondly, in studying knowledge, both traditions have been similarly influenced by research in cybernetics and systems theory, and more recent approaches in EE and biosemiotics also resort to non-Darwinian theories of evolution. In so doing, both schools understand organisms as autonomous systems capable of selforganizing and self-regulating. Biosemioticians, however, have emphasized the teleological character (i.e., the goal-directedness) of self-organizing and selfregulating activities while Non-Adaptationist and Applied Evolutionary Epistemologists have highlighted the independent character of such activities from an outer world.

Thirdly, we have shown that the different schools all share an interest in the organism-environment relationship. Nevertheless, whereas non-adaptationist EE, as well as biosemiotics, resort to an old cosmology when defining the organismenvironment relation, a cosmology that relies upon a sharp distinction between ontology and epistemology, AEE draws upon a new worldview, up-to-date with the latest research in biological, socio-anthropological, and physical sciences, a worldview in which epistemology and ontology ultimately come to coincide.

By analyzing how (A)EE and biosemiotics compare to one another, we have laid bare problems faced by biosemioticians and overcome by scholars active in non-adaptationist EE and AEE. On such grounds, we contend that biosemiotics necessitates a revision of the way it accounts for the relation between biological organisms and otherworldly phenomena. By drawing upon the recent history of AEE, biosemiotics might find the means to operate such change and continue to build up its path, alongside that of (A)EE.

Acknowledgements Parts of this paper were presented at the 19th Annual Gatherings in Biosemiotics that was held in Moscow, Russia, in 2019. We thank the audience for useful comments. We are furthermore grateful to the editors of this inspiring volume for inviting us to contribute. Gontier in addition acknowledges the financial support of FCT, the Portuguese Foundation for Science and Technology, Grant ID DL57/2016/CP1479/CT0066 and Project IDs: UID/FIL/00678/2019 \& UIDB/00678/2020. 


\section{References}

Artmann S (2005) Biosemiotics as a structural science: between the forms of life and the life of forms. J Biosemiotics 1:229-265

Barbieri M (2014) From biosemiotics to code biology. Biol Theory 9(2):239-249

von Bertalanffy L (1968) General system theory: foundations, development, applications. George Braziller, New York

Bradie M (1986) Assessing evolutionary epistemology. Biol Philos 1:401-459

Bradie M, Harms W (2001) (substantive revision: 2016). Evolutionary epistemology. Stanford encyclopedia of philosophy. http://plato.stanford.edu/entries/epistemology-evolutionary/. Accessed Jan 2020

Brier S (2006) Biosemiotics. Int Encycl Lang Linguist 2:31-40

Brier S (2015) Can biosemiotics be a 'science' if its purpose is to be a bridge between the natural, social and human sciences? Prog Biophys Mol Biol 119(3):576-587

Brigandt I, Love A (2017) Reductionism in biology. In Zalta EN (ed) The Stanford encyclopedia of philosophy. Spring. https://plato.stanford.edu/archives/spr2017/entries/reduction-biology/. Accessed 4 June 2019

Bruni LE (2008) Cellular semiotics and signal transduction. In: Barbieri M (ed) Introduction to biosemiotics. The new biological synthesis. Springer, Dordrecht, pp 365-407

Campbell DT (1974a) Evolutionary epistemology. In: Schlipp PA (ed) The philosophy of Karl Popper, vol I. La Salle, Chicago, IL, pp 413-459

Campbell DT (1974b) Downward causation in hierarchically organized biological systems. In: Ayala FJ, Dobzhansky T (eds) Studies in the philosophy of biology: reduction and related problems. Palgrave, London, pp 179-186

Clark A, Chalmers DJ (1998) The extended mind. Analysis 58(1):7-19

Dawkins R (1983) Universal Darwinism. In: Hull DL, Ruse M (eds) The philosophy of biology. Oxford University Press, Oxford, 15-35 [First published in Bendall DS (ed) (1998) Evolution from molecules to man. Cambridge University Press, Cambridge, pp 403-425]

Deely J (2013) The quasi-error of the external world: an essay for Thomas A. Sebeok, in memoriam. Cybern Hum Knowing 10(1):25-46

Diettrich O (1998) On some relations between cognitive and biological evolution. In: Van de Vijver G, Salthe S, Delpos M (eds) Evolutionary systems. Kluwer, Dordrecht, pp 319-340

Diettrich O (2001) A physical approach to the construction of cognition and to cognitive evolution. Found Sci 6(4):273-341

Diettrich O (2004) Cognitive evolution. In: Wuketits FM, Antweiler C (eds) Handbook of evolution, Vol. 1: the evolution of human societies and cultures. Wiley-VCH Verlag GmbH \& Co. KgaA, Weinheim, pp 25-75

Diettrich O (2006) The biological boundary conditions for our classical physical world view. In: Gontier $\mathrm{N}$ et al (eds) Evolutionary epistemology, language and culture. Springer, Dordrecht, pp 67-93

Eco U (1984) Semiotics and the philosophy of language. Indiana University Press, Bloomington and Indianapolis

Facoetti M (2017) Evolution, knowledge, and reality: a defence of non-adaptationist evolutionary epistemology. Master thesis. https://dspace.library.uu.nl/handle/1874/353294. Accessed 22 May 2020

Facoetti M (2020) Donald Davidson's critiques of conceptual relativism applied to non-adaptationist evolutionary epistemology and refuted. Found Sci 25:357-374

Facoetti M (2021) United in diversity: an organic overview of non-adaptationist evolutionary epistemology. J Gen Philos Sci 52:211-225

Favareau D (2007) The evolutionary history of biosemiotics. In: Barbieri M (ed) Introduction to biosemiotics: the new biological synthesis. Springer, Dordrecht, pp 1-67

Favareau D et al (2017) How can the study of the humanities inform the study of biosemiotics? Biosemiotics 10:9-31 
Gensini S (2002) Elementi di semiotica. Carocci editore, Roma

von Glasersfeld E (1981) Einführung in den Radikalen Konstruktivismus. In: Watzlawick P (ed) Die Erfundene Wirklichkeit. Piper, Munich, pp 16-38

von Glasersfeld E (1984) An introduction to radical constructivism. In: Watzlawick P (ed) The invented reality. Norton, New York, pp 17-40

von Glasersfeld E (1995) Radical constructivism. The Palmer Press, London

Gontier N (2006a) Introduction to evolutionary epistemology, language and culture. In: Gontier N et al (eds) Evolutionary epistemology, language and culture. Springer, Dordrecht, pp 1-29

Gontier N (2006b) Evolutionary epistemology. Internet encyclopaedia of philosophy. http://www. iep.utm.edu/evo-epis/\#H6. Accessed Jan 2020

Gontier N (2012) Applied evolutionary epistemology: a new methodology to enhance interdisciplinary research between the life and human sciences. Kairos 4:7-49

Gontier N (2017) What are the levels and mechanisms/processes of language evolution? Lang Sci 63:12-43

Gontier N (2018) On how epistemology and ontology converge through evolution: the applied evolutionary epistemological approach. In: Wuppuluri S, Doria FA (eds) The map and the territory. Springer, Dordrecht, pp 533-569

Gontier N, Bradie M (2017) Acquiring knowledge on species-specific biorealities: the applied evolutionary epistemological approach. In: Joyce R (ed) The routledge handbook of evolution and philosophy. Routledge, London, pp 136-152

Gould SJ (1977) Ontogeny and phylogeny. Harvard University Press, Cambridge, MA

Gould SJ, Lewontin R (1979) The spandrels of San Marco and the panglossian paradigm: a critique of the adaptationist programme. Proc R Soc London, Ser B 205:581-598

Hahlweg K, Hooker C (eds) (1989) Issues in evolutionary epistemology. State University of New York Press, Abany, NY

Hoffmeyer J (2010) God and the world of signs: semiotics and the emergence of life. Zygon 45 (2):367-390

Hoffmeyer J (2011) Biology is immature biosemiotics. In: Emmeche C, Kull K (eds) Towards a semiotic biology: life is the action of signs. Imperial College Press, London, pp 43-65

Hoffmeyer J, Emmeche C (1991) Code-duality and the semiotics of nature. In: Anderson M, Merrell F (eds) On semiotic modelling. Mouton de Gruyter, Berlin, New York, pp 117-166

Hoffmeyer J, Kull K (2011) Theories of signs and meaning: views from copenhagen and tartu. In: Emmeche C, Kull K (eds) Towards a semiotic biology: life is the action of signs. Imperial College Press, London, pp 263-286

Hull DL (1988) Science as a process: an evolutionary account of the social and conceptual development of science. The University of Chicago Press, Chicago

James W (1907) Pragmatism: a new name for some old ways of thinking. Project Gutenberg, http:// www.gutenberg.org/files/5116/5116-h/5116-h.htm

Kalevi K (1998) Semiotic ecology: different natures in the semiosphere. Sign Syst Stud 26:344-371

Kull K (1999) Biosemiotics in the twentieth century: a view from biology. Semiotica 127 (1/4):385-414

Kull K (2009a) Biosemiotics: to know, what life knows. Cybern Hum Knowing 16(1-2):81-88

Kull K (2009b) The importance of semiotics to university: semiosis makes the world locally plural. In: Deely J, Sbrocchi LG (eds) Semiotics 2008: specialization, semiosis, semiotics. Legas, Ottawa, pp 494-514

Kull K (2009c) Vegetative, animal, and cultural semiosis: the semiotic threshold zones. Cognit Semiotics 4:8-27

Kull K (2014) Zoosemiotics is the study of animal forms of knowing. Semiotica 198:47-60

Kull K (2015) Introduction to biosemiotics. In: Trifonas PP (ed) International handbook of semiotics. Springer, Dordrecht, pp 521-533

Kull K (2018) On the logic of animal umwelten: the animal subjective present and zoosemiotics of choice and learning. In: Marrone G, Mangano D (eds) Semiotics of animals in culture: Zoosemiotics 2.0. Springer, Cham, pp 135-148 
Kull K, Emmeche C, Favareau D (2011a) Biosemiotic research questions. In: Emmeche C, Kull K (eds) Towards a semiotic biology: life is the action of signs. Imperial College Press, London, pp $67-90$

Kull K, Emmeche C, Hoffmeyer J (2011b) Why biosemiotics? An introduction to our view on the biology of life itself. In: Emmeche C, Kull K (eds) Towards a semiotic biology: life is the action of signs. Imperial College Press, London, pp 1-21

Kull K et al (2011c) Theses on biosemiotics: prolegomena to a theoretical biology. In: Emmeche C, Kull K (eds) Towards a semiotic biology: life is the action of signs. Imperial College Press, London, pp 25-41

Lewontin RC (1982) Organism and environment. In: Plotkin HC (ed) Learning, development and culture. Wiley, New York

Lewontin RC (1983) Gene, organism, and environment. In: Bendall DS (ed) Evolution from molecules to men. Cambridge University Press, Cambridge

Lewontin RC (2000) The triple helix. Harvard University Press, Cambridge, MA

Liu CH, Matthews R (2005) Vygotsky's philosophy: constructivism and its criticisms examined. Int Educ J 6(3):386-399

Lorenz K (1941) Kant's Lehre vom Apriorischen im Lichte gegenwärtiger Biologie. Blätter Dtsch Philos 15:94-125

Lorenz K (1977) Behind the mirror: a search for a natural history of human knowledge. Methuen, London

Löwenhard P (1989) The mind-body problem: some neurobiological reflections. In: HoyningenHuene P, Wuketits FM (eds) Reductionism and systems theory in the life sciences. Kluwer Academic Publishers, Dordrecht, pp 85-135

Magnani L (2017) The abductive structure of scientific creativity: an essay on the ecology of cognition. Springer, Heidelberg

Maturana HR (1970) Biology of cognition. In: BCL report 9.0. University of Illinois, Champaign, IL

Maturana HR, Varela FJ (1980) Autopoiesis and cognition: the realization of the living. D. Reidel, Dordrecht

Munz P (1993) Philosophical Darwinism: on the origin of knowledge by means of natural selection. Routledge, London

Nöth W (1998) Ecosemiotics. Sign Syst Stud 26:332-343

Odling-Smee FJ, Laland KN, Feldman MW (1996) Niche construction. Am Nat 147:641-648

Pattee HH (ed) (1973) Hierarchy theory: the challenge of complex systems. Braziller, New York

Pattee HH, Kull K (2011) Between physics and semiotics. In: Emmeche C, Kull K (eds) Towards a semiotic biology: life is the action of signs. Imperial College Press, London, pp 213-233

Peirce CS (1931-1935) Collected papers of Charles Sanders Peirce, vol 1-8. Harvard University Press, Cambridge

Peirce CS $(1992,1999)$ The essential Peirce, 2 volumes. Indiana University Press, Bloomington

Piaget J (1970) Genetic epistemology (trans: Duckworth E). Columbia University Press, New York

Plotkin H (1994) Darwin machines and the nature of knowledge: concerning adaptations, instinct and the evolution of intelligence. Cambridge University Press

Popper KR (1963) Conjectures and refutations. Routledge \& Kegan Paul, London

Popper KR (1972) Objective knowledge: an evolutionary approach. Clarendon Press, Oxford

Quine WV (1969) Naturalized epistemology. In: Quine WV (ed) Ontological relativity and other essays. Colombia University Press, New York, pp 69-90

Riedl R (1984) Biology of knowledge: the evolutionary basis of reason. John Wiley \& Sons, Chichester

Riegler A (2001) Towards a radical constructivist understanding of science. Found Sci 6:1-30

Riegler A (2006) Like cats and dogs: radical constructivism and evolutionary epistemology. In: Gontier $\mathrm{N}$ et al (eds) Evolutionary epistemology, language and culture. Springer, Dordrecht, pp 47-65

Rorty R (1980) Philosophy and the mirror of nature. Blackwell, Oxford 
Rothschild FS (1962) Laws of symbolic mediation in the dynamics of self and personality. Ann N Y Acad Sci 96:774-784

Salthe SN (1985) Evolving hierarchical systems: their structure and representation. Columbia University Press, New York

Sebeok TA (1994) Signs: an introduction to semiotics. University of Toronto Press, Toronto

Sebeok TA (1996) Signs, bridges, origins. In: Trabant J (ed) Origins of language. Collegium Budapest, Budapest, pp 89-115

Shannon CE (1948) A mathematical theory of communication. Bell Syst Tech J 27:379-423 \& 623-656

Sharov AA (1999) Pragmatism and umwelt-theory. http://alexei.nfshost.com/biosem/txt/umwelt. html. Accessed 13 Dec 2018

Sharov AA (2016) Evolutionary biosemiotics and multilevel construction networks. Biosemiotics 9 (3):399-416

Sharov AA (2018) Mind, agency, and biosemiotics. J Cognit Sci 192:195-228

Sharov AA (n.d.) What is biosemiotics? http://alexei.nfshost.com/biosem/geninfo.html. Accessed 13 Dec 2018

Sharov AA, Maran T, Tønnessen M (2015) Towards synthesis of biology and semiotics. Biosemiotics 8:1-7

Sharov AA, Maran T, Tønnessen M (2016) Comprehending the semiosis of evolution. Biosemiotics $9(1): 1-6$

Sharov AA, Vehkavaara T (2015) Protosemiosis: agency with reduced representation capacity. Biosemiotics 8(1):103-123. [Available at (without page numbers): https://www.ncbi.nlm.nih. gov/pmc/articles/PMC4414345/. Accessed 23 Sept 2019]

Simon HA (1962) The architecture of complexity: hierarchic systems. Proc Am Philos Soc $106: 467-482$

Tinbergen N (1963) On aims and methods in ethology. Z Tierpsychol 20:410-443

Tooby J, DeVore I (1987) The reconstruction of hominid evolution through strategic modeling. In: Kinzey WG (ed) The evolution of human behavior: primate models. SUNY Press, Albany, NY, pp 183-237

Toulmin S (1972) Human understanding: the collective use and evolution of concepts. Princeton University Press, Princeton

von Uexküll J (1921) Umwelt und Innenwelt der Tiere. 2. verm. u. verb. Aufl. J. Springer, Berlin

von Uexküll J (1928) Theoretische Biologie 2, 2nd edn. J. Springer, Berlin

von Uexküll J (1934) A stroll through the worlds of animals and men: A picture book of invisible worlds. Semiotica 89(4):319-391. [Originally published in Schiller CH (ed) (1957) Instinctive behavior. International Universities Press, Madison, CT, 5-80]

von Uexküll J (1937) The new concept of umwelt: a link between science and the humanities. Semiotica 134(1/4):111-123

von Uexküll J (1940) Bedeutungslehre. J.A. Barth, Leipzig

Vehkavaara T (2002) Why and how to naturalize semiotic concepts for biosemiotics. Sign Syst Stud 30(1):293-313

Vehkavaara T (2003) Natural self-interest, interactive representation, and the emergence of objects and Umwelt: an outline of basic semiotic concepts for biosemiotics. Sign Syst Stud 31 (2):547-587

Vollmer G (1984) Mesocosm and objective knowledge: on problems solved by evolutionary epistemology. In: Wuketits FM (ed) Concepts and approaches in evolutionary epistemology: towards an evolutionary theory of knowledge. D. Reidel, Dordrecht, pp 69-121

Vollmer G (1987) [1975] Evolutionäre Erkenntnistheorie, 4th edn. Hirzel, Stuttgart

Whittaker RH, Margulis L (1978) Protist classification and the kingdoms of organisms. Biosystems 10:3-18

Wiener N (1948) Cybernetics: or control and communication in the animal and the machine. MIT Press, Cambridge, MA 
Woese CR, Kandler O, Wheelis ML (1990) Towards a natural system of organisms: proposal for the domains Archaea, Bacteria, and Eucarya. PNAS 87(12):4576-4579

Wuketits FM (1989) Organisms, vital forces, and machines: classical controversies and the contemporary discussion 'reductionism vs. holism'. In: Hoyningen-Huene P, Wuketits FM (eds) Reductionism and systems theory in the life sciences. Kluwer Academic Publishers, Dordrecht, pp 85-135

Wuketits FM (1992) Adaptation, representation, construction: an issue in evolutionary epistemology. Evol Cognit 2:151-162

Wuketits FM (1998) Functional realism. La Nuova Crit 31-32:5-21

Wuketits FM (2006) Evolutionary epistemology: the non-adaptationist approach. In: Gontier $\mathrm{N}$ et al (eds) Evolutionary epistemology, language and culture. Springer, Dordrecht, pp 33-46 